\title{
Identification of an Alternative rRNA Post-transcriptional Maturation of 26S rRNA in the Kingdom Fungi
}

\author{
Alfonso Navarro-Ródenas ${ }^{1}$, Andrea Carra ${ }^{2}$ and Asunción Morte ${ }^{1 *}$ \\ ${ }^{1}$ Departamento Biología Vegetal (Botánica), Facultad de Biología, Universidad de Murcia, Murcia, Spain, \\ ${ }^{2}$ Istituto per la Protezione Sostenibile delle Piante, Consiglio Nazionale delle Ricerche, Turin, Italy
}

OPEN ACCESS

Edited by:

Raffaella Balestrini,

Consiglio Nazionale delle

Ricerche (CNR), Italy

Reviewed by: Antonella Amicucci,

University of Urbino, Italy Francesco Paolocci,

Consiglio Nazionale delle

Ricerche (CNR), Italy

*Correspondence:

Asunción Morte

amorte@umu.es;

amorte@um.es

Specialty section:

This article was submitted to Fungi and Their Interactions,

a section of the journal

Frontiers in Microbiology

Received: 30 January 2018

Accepted: 27 April 2018

Published: 25 May 2018

Citation:

Navarro-Ródenas A, Carra A and

Morte A (2018) Identification of an

Alternative rRNA Post-transcriptional

Maturation of 26S rRNA

in the Kingdom Fungi.

Front. Microbiol. 9:994.

doi: 10.3389/fmicb.2018.00994
Despite of the integrity of their RNA, some desert truffles present a non-canonical profile of $\mathrm{rRNA}$ where $3.3 \mathrm{~kb}$ is absent, $1.8 \mathrm{~kb}$ is clear and a band of $1.6 \mathrm{~kb}$ is observed. A similar rRNA profile was identified in organisms belonging to different life kingdoms, with the exception of the Kingdom Fungi, as a result of a split LSU rRNA called hidden gap. rRNA profiles of desert truffles were analyzed to verify the presence of the non-canonical profile. The RNA of desert truffles and yeast were blotted and hybridized with probes complementary to LSU extremes. RACE of LSU rRNA was carried out to determine the LSU rRNA breakage point. LSU rRNA of desert truffles presents a post-transcriptional cleavage of five nucleotides that generates a hidden gap located in domain D7. LSU splits into two molecules of 1.6 and $1.8 \mathrm{~kb}$. Similar to other organisms, a UAAU tract, downstream of the breakage point, was identified. Phylogenetic comparison suggests that during fungi evolution mutations were introduced in the hypervariable D7 domain, resulting in a sequence that is specifically post-transcriptionally cleaved in some desert truffles.

Keywords: Terfezia, Tirmania, desert truffles, hidden gap, LSU rRNA, domain D7

\section{INTRODUCTION}

The fungi called "desert truffles" or "turmas" comprise certain species of mycorrhizal fungi, most belonging to the order Pezizales (division Ascomycota), which produce hypogeous and edible fruit bodies. Their distribution is limited to arid and semi-arid regions, mainly in the Mediterranean Basin and the Middle East (Moreno et al., 2014; Zambonelli et al., 2014). The most appreciated genera for their edible ascocarps are Terfezia (Tul. \& Tul.) Tul. \& Tul., Picoa Vittad. 1831 and Tirmania Chatin 1892. Most of the species of Terfezia, Picoa, and Tirmania establish mycorrhizal symbiosis with plants of the family Cistaceae, mainly with perennial or annual species of the genus Helianthemum (Morte and Andrino, 2014). This symbiotic association plays a key role in the maintenance of Mediterranean shrubland and xerophytic grassland ecosystems, preventing erosion and desertification (Honrubia et al., 1992). In addition, Terfezia claveryi Chatin was the first desert truffle species to be cultivated (Morte et al., 2008, 2017). During recent years, this species has become an agricultural alternative in semi-arid areas due to its appreciated edible valuable product with low water requirements for cultivation (Morte et al., 2010).

Our most recent studies on desert truffles used molecular biology techniques, which often require the isolation of intact RNA (Navarro-Ródenas et al., 2012, 2013). As a routine, RNA evaluation is based on the integrity of the small (SSU) and large (LSU) subunits of ribosomal 
RNAs (rRNA) that must be visualized as sharp and clear $\sim 1.8$ and $\sim 4.0 \mathrm{~kb}$ bands in a denaturing agarose gel or in a bioanalyzer. The canonical band profile in eukaryotic samples is a LSU rRNA band twice as intense as the SSU rRNA band. Nevertheless, in some organisms from a wide range of biological groups including bacteria, cyanobacteria, protozoa, insects, helminthes, fish and mammals, despite their RNA integrity, a non-canonical profile of rRNA bands has also been observed, where LSU is nearly or totally absent and a second or third band of different size may appear (Stevens and Pachler, 1972; Lava-Sanchez and Puppo, 1975; Pellegrini et al., 1977; Eckert et al., 1978; Leon et al., 1978; Leipoldt and Engel, 1983; Ware et al., 1985; Burgin et al., 1990; Mertz et al., 1991; van Keulen et al., 1991; Azpurua et al., 2013). In these organisms, an unusual post-transcriptional processing of LSU rRNA has been reported, which results in its breakage into two subunits called 28S $\alpha$ and 28S $\beta$ (Stevens and Pachler, 1972; Lava-Sanchez and Puppo, 1975; Pellegrini et al., 1977; Eckert et al., 1978; Leon et al., 1978; Ware et al., 1985; Burgin et al., 1990; Mertz et al., 1991; van Keulen et al., 1991; Azpurua et al., 2013). These subunits are non-covalently bound (Ishikawa and Newburgh, 1972; Ishikawa, 1977a,b; Winnebeck et al., 2010) and migrate near the $18 \mathrm{~S}$ rRNA. The break point, called the "hidden break" (Ishikawa and Newburgh, 1972) was subsequently found not to be a single cleavage point, but the site of a double-cut event producing excised fragments of variable length in different species, and referred to as the "hidden gap" (Ishikawa, 1977a). In the case of naked mole-rat the presence of a cleaved 28S rRNA has been associated with increased translation fidelity which may contribute to the unusual longevity of this mammal (Azpurua et al., 2013).

The LSU rRNA hidden break has not been reported in fungi yet. However, when T. claveryi RNA is analyzed in a bioanalyzer after thermal denaturation, the non-canonical band profile is displayed, where LSU rRNA is almost missing and a typical SSU rRNA $(1.8 \mathrm{~kb})$ and a peak similar to bacterial $16 \mathrm{~S}$ rRNA $(1.6 \mathrm{~kb})$ are clearly observed. We are perhaps faced with a unique event throughout the evolutionary history of the Kingdom Fungi. Our hypothesis is that the non-canonical rRNA band profile observed in some desert truffles is due to a specific post-transcriptional processing of LSU called "hidden gap," even though it had not been observed in fungi before. To explain this pattern, the structure of $T$. claveryi LSU rRNA was studied using molecular techniques, with the main objective of uncovering the existence and mapping the position of a hidden gap in the LSU rRNA in fungi.

\section{MATERIALS AND METHODS}

\section{RNA Isolation and Microfluid Analyzer}

Total RNA was isolated from, at least, three different samples of ascocarps of each of the desert truffles T. claveryi, Terfezia arenaria (Moris) Trappe and Picoa lefebvrei (Pat.) Maire, mycelium of Tirmania nivea (Desf.) Trappe or yeast using spin columns (RNeasy Plant Mini Kit, Qiagen) according to the manufacturer's instructions. In the case of T. claveryi, the CTAB protocol (Chang et al., 1993) or the phenol and chloroform extraction (Kay et al., 1987) were also used for RNA extraction, both in ascocarps and mycelium.

For quality and integrity analysis, T. claveryi, T. arenaria, $T$. nivea, and $P$. lefebvrei RNAs were electrophoretically separated in agarose gel or with an Agilent 2100 Bioanalyzer, using a 2100 expert_Eukaryote total RNA Nano Chip. When RNA was heat denatured prior to separation, RNA was incubated at $95^{\circ} \mathrm{C}$ for $2 \mathrm{~min}$.

\section{Northern Blots}

RNA was electrophoresed in denaturing $1.2 \%(\mathrm{w} / \mathrm{v})$ agarose gels prepared in double-distilled $\mathrm{H}_{2} \mathrm{O}$ and $1 \mathrm{X}$ MOPS buffer. Formaldehyde was added to a final concentration of $7 \%$ (vol/vol). Samples were denatured at $65^{\circ} \mathrm{C}$ for $10 \mathrm{~min}$, placed on ice, and then loaded. Electrophoresis was carried out at $\sim 50 \mathrm{~V}$ for $6 \mathrm{~h}$ in $1 \mathrm{X}$ MOPS containing $1,5 \%$ formaldehyde as running buffer. Samples were blotted to positively charged Nylon membranes (Roche) in SSC 10X overnight. The membranes were hybridized with probes (Supplementary Figure S1) labeled with the PCR DIG labeling mix (Roche) using the primers listed in Table $\mathbf{1 .}$ Hybridizations were performed at $50^{\circ} \mathrm{C}$ in DIG Easy Hyb (Roche) overnight. Stringency washings were performed with $0.1 \mathrm{X}$ SSC$0.1 \%(\mathrm{w} / \mathrm{v}) \mathrm{SDS}$, at $68^{\circ} \mathrm{C}$ for $30 \mathrm{~min}$. Target RNA was detected according to the manufacturer's protocol (Roche Diagnostics, Germany) using CSPD as chemiluminescent substrate.

\section{RACE}

RACE experiments were carried out as described by ScottoLavino et al. (2006) with minor modifications. For $5^{\prime} \mathrm{RACE}$ $2 \mu \mathrm{g}$ of DNase-treated RNA were denatured at $85^{\circ} \mathrm{C}$ for $5 \mathrm{~min}$ and reverse transcribed with Superscript IV (Invitrogen) in a $20 \mu \mathrm{l}$ reaction at $55^{\circ} \mathrm{C}$ for $10 \mathrm{~min}$ using a $T$. claveryi $5^{\prime} \mathrm{RT}$ specific primer. After digestion of residual RNA with $1 \mathrm{U}$ of RNase $\mathrm{H}$ (Invitrogen), cDNA was purified with a silica column (Wizard $^{\circledR}$ SV Gel and PCR Clean-Up System, Promega) and poly(A) tailed with terminal transferase (Roche). Three rounds of PCR were performed, the first with primers $5^{\prime}$ RACE oligo dT adaptor, LR9 and $5^{\prime}$ RACE outer adaptor, the second with primers $5^{\prime}$ RACE adaptor and $26 \mathrm{~S} 5^{\prime}$ RACEnest 2 and the third with primers $5^{\prime} \mathrm{RACE}$ adaptor and $26 \mathrm{~S} 5^{\prime}$ RACEnest3. For $3^{\prime}$ RACE, $2 \mu \mathrm{g}$ of DNase-treated RNA (Turbo DNA-free kit, Ambion) were polyadenylated with $\operatorname{Poly}(\mathrm{A})$ polymerase (Ambion) and reverse transcribed with an oligo-(dT)-adapter primer. First round and nested PCRs were performed with the primers shown in Table 1 and Supplementary Figure S1. PCR products were cloned into pCR 2.1 TOPO vector (Invitrogen) and sequenced in forward and reverse orientation using universal primers (M13) recognizing vector sites encompassing the cloning site.

The nucleotide sequences of LSU rDNA were obtained from Joint Genome Institute (JGI ${ }^{1}$ ) for T. boudieri (Terbo2; JGI), T. claveryi (Tercla1; JGI), Tuber melanosporum (Tubme1; JGI), Pyronema confluens (Pyrco1; JGI) and Morchella conica (Morco; JGI), and Saccharomyces cerevisae (NR_132209.1) from NCBI. Moreover, we sequenced and deposited at NCBI the region

\footnotetext{
${ }^{1}$ https://genome.jgi.doe.gov
} 
TABLE 1 | List of primers used.

\begin{tabular}{|c|c|c|c|}
\hline Primer code & DNA sequence $\left(5^{\prime}-3^{\prime}\right)$ & Sense & Use \\
\hline 26S_5'_for & GTGAAGCGGCAAAAGCTCAGAT & S & 26S_5'-DIG-probe \\
\hline 26S_5'_rev & TTCCAACCCCAAGGCCTCTAAT & AS & 26S_5'-DIG-probe \\
\hline LR10R & GACCCTGTTGAGCTTGA & S & 26S_3'-DIG-probe \\
\hline LR12 & GACTTAGAGGCGTTCAG & AS & 26S_3'-DIG-probe \\
\hline Adaptor & ACGCTACGTAACGGCATGACAGTG & & $26 S \alpha \_3^{\prime}-\mathrm{RACE}$ \\
\hline Oligo-(dT)-adaptor & GCTGTCAACGATACGCTACGTAACGGC ATGACAGTGd(T'12)VN & & $26 S \alpha \_3^{\prime}-\mathrm{RACE}$ \\
\hline LR3R & GTCTTGAAACACGGACC & S & $26 \mathrm{~S} \alpha \_3^{\prime}-\mathrm{RACE}$ \\
\hline LR7R & TACTACCACCAAGATCT & S & $26 \mathrm{~S} \alpha \_3^{\prime}-\mathrm{RACE}$ \\
\hline LR9 & AGAGCACTGGGCAGAAA & AS & $26 S \beta \_5^{\prime}-\mathrm{RACE}$ \\
\hline 5'RACE Oligo-(dT)-adaptor & GCTGTCAACGATACGCTACGTAACGGCAT GACAGTG(T'17)VN & & $26 S \beta \_5^{\prime}-$ RACE \\
\hline 5'RACE_out_adaptor & TACGCTACGTAACGGCATGA & & $26 S \beta \_5^{\prime}-\mathrm{RACE}$ \\
\hline 5'RACE_adaptor & ACGCTACGTAACGGCATGACAGTG & & $26 S \beta \_5^{\prime}-\mathrm{RACE}$ \\
\hline 5'RACE_RT & TAGGGACAGTGGGAATCTCG & AS & $26 S \beta \_5^{\prime}-\mathrm{RACE}$ \\
\hline Ter26S_5'-RACE_Nest2 & ATTCCCCCAGTCCGTACCAGTTCT & AS & $26 S \beta \_5^{\prime}-$ RACE \\
\hline Ter26S_5'-RACE_Nest3 & GGGTACGACCTGGCGTGAAAATTA & AS & $26 S \beta \_5^{\prime}-\mathrm{RACE}$ \\
\hline
\end{tabular}

encompassing the hidde gap of T. arenaria (MH160402), Terfezia extremadurensis (MH160403), Terfezia fanfani (MH160404), T. nivea (MH160405). All the sequences were aligned using the program ClustalO (Sievers et al., 2011).

\section{RESULTS}

\section{Electrophoretic Profiles of the Heat-Denatured and Native RNA Samples From Terfezia spp., Tirmania nivea and Picoa lefebvrei}

The integrity of total RNA samples from T. claveryi, T. arenaria, T. nivea, and $P$. lefebvrei in heat-denatured or native conditions was assayed. For all the species, in native conditions, both the SSU and the LSU rRNA bands were identified (Figure 1). In addition, a peak similar of $1.6 \mathrm{~kb}$ was barely but clearly observed in T. claveryi, T. arenaria, and T. nivea (Figure 1). In T. arenaria the LSU peak seems smaller than in other species but this is the result of a partial denaturation during RNA extraction (Leaver, 1973). The third peak, higher than $4.0 \mathrm{~kb}$ and observed in all species under native condition, should be interpreted as an artifact. After heat denaturation, RNA samples from $P$. lefebvrei did not show significant differences in band profile, conversely, the presence of the LSU fragment was no longer observed in T. claveryi, T. arenaria, or T. nivea (Figure 1). On the other hand, the peak belonging to a fragment of approximately $1.8 \mathrm{~kb}$, typical of the $18 \mathrm{~S}$ rRNA, was still observed and the intensity of the $18 \mathrm{~S}$ band had increased, as indicated by a greater FU (fluorescence unit) value in comparison with the FU value of the $18 \mathrm{~S}$ rRNA peak for each non-heat-denatured sample (Figure 1). The presence of a second anomalous peak with an approximate size of $1.6 \mathrm{~kb}$ and intensity similar to the $18 \mathrm{~S}$ peak was observed only in T. nivea and Terfezia species RNA (Figure 1). Low molecular weight RNA fractions, including a peak with an approximate size of 190 bp corresponding to $5.8 \mathrm{~S}$, were observed in both heat-denatured or non-heatdenatured conditions with similar intensity. Similar band profiles were observed in several ascocarps and with different RNA extraction protocols for all the species. For $T$. claveryi, the band profiles were also confirmed in RNA extracted from mycelium.

\section{Terfezia LSU Is Fragmented in Two Asymmetrical Subunits}

Preliminary attempts to amplify different portions of the LSU rRNA by RT-PCR always failed when primers where designed encompassing a region of about $1 \mathrm{~kb}$ asymmetrically positioned within the $3^{\prime}$ half of the LSU rRNA molecule. On the basis of this observation and to confirm the presence of the hidden gap, two probes were designed, named 26S_5' and 26S_3', complementary to the $5^{\prime}$ terminal and $3^{\prime}$ terminal regions of T. claveryi LSU rRNA, respectively. They were used in Northern blot experiments with total RNA from $T$. claveryi, $T$. arenaria and yeast. In the case of yeast total RNA, both 26S_5' and 26S_3' probes detected the same RNA species of approximately $3.3 \mathrm{~kb}$ (Figure 2). However, in the case of $T$. claveryi and $T$. arenaria RNA, the $26 \mathrm{~S} \_5^{\prime}$ probe detected an RNA species of approximately $1.6 \mathrm{~kb}$ and the 26S_3' probe detected another of approximately $1.8 \mathrm{~kb}$ (Figure 2). A very faint $3.3 \mathrm{~kb}$ band was also detected in T. claveryi RNA, suggesting that very low amounts of the uncut species were still present. When the blot hybridized with the $3^{\prime}$ probe was reprobed with the $5^{\prime}$ probe, no change in the $26 \mathrm{~S}$ band of yeast rRNA was observed, but in both Terfezia species a distinct signal of about $1.6 \mathrm{~kb}$ was observed below the pre-existing $1.8 \mathrm{~kb}$ band (Figure 2). These results allowed us to conclude that: (i) the hidden gap maps within $1.6 \mathrm{~kb}$ from the $5^{\prime}$ extreme and $1.8 \mathrm{~kb}$ from the $3^{\prime}$ extreme of LSU, (ii) the $1.8 \mathrm{~kb}$ band, co-migrates with uncleaved $18 \mathrm{~S} \mathrm{RNA}$ and corresponds to the $3^{\prime}$ portion of LSU rRNA, (iii) the faint $3.3 \mathrm{~kb}$ band observed in $T$. claveryi corresponds to an uncut version of LSU rRNA and (iv) the absence of $28 \mathrm{~S}$ rRNA is not due to a non-specific degradation. 

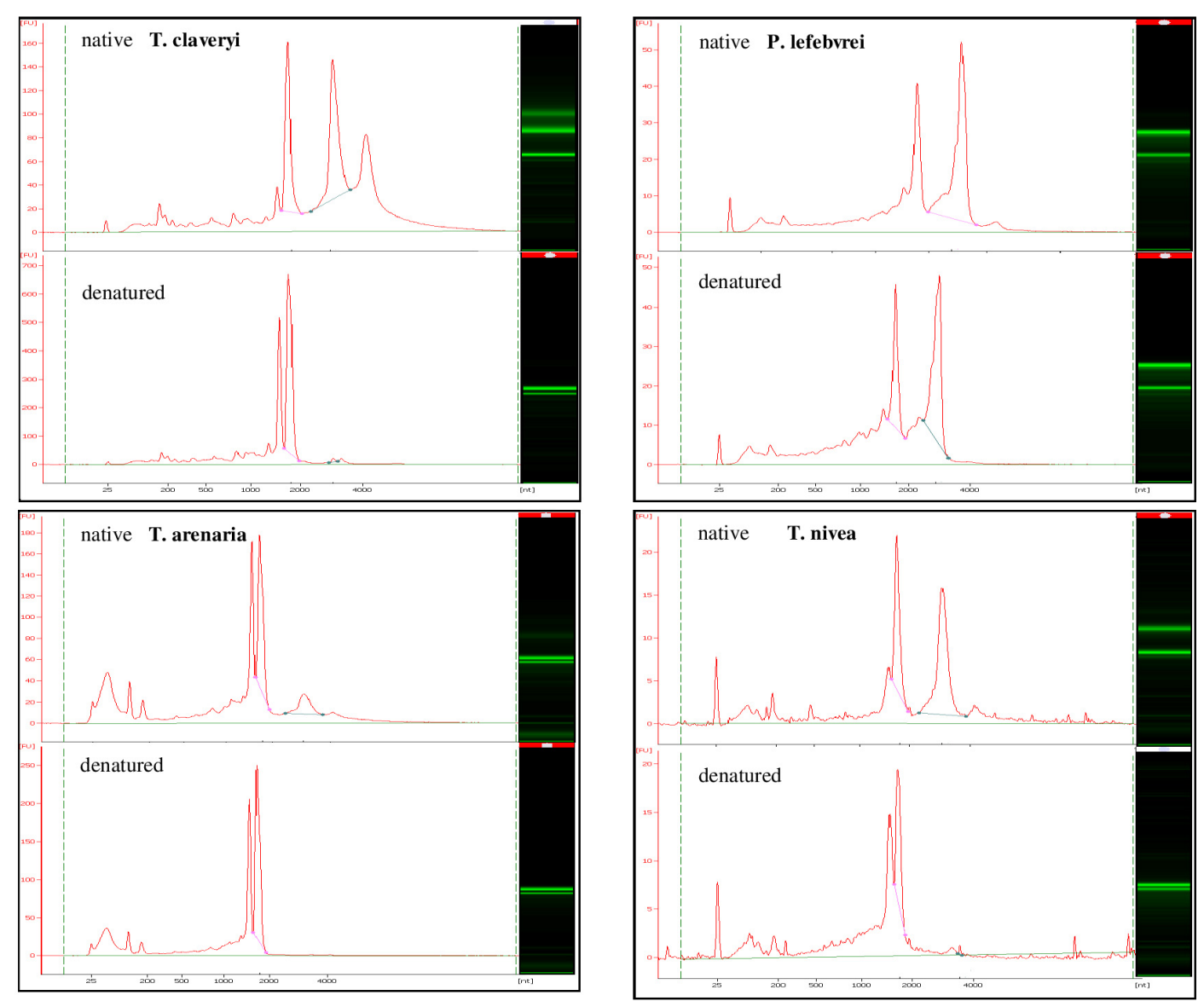

FIGURE 1 | Bioanalyzer electrophoretic profiles of T. claveryi, P. lefebvrei, T. arenaria and T. nivea RNAs without heat-denaturation (native) and after heat-denaturation (denatured); nt, nucleotide length; FU, fluorescence unit.

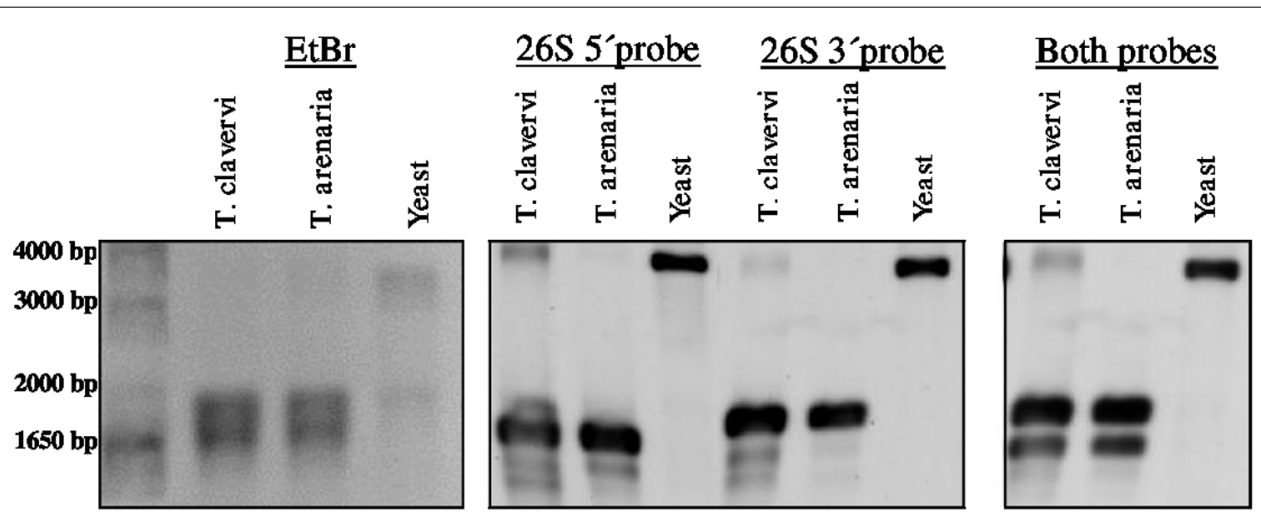

FIGURE 2 | Denaturing formaldehyde-agarose gel electrophoresis of total RNA from T. claveryi, T. arenaria and yeast, stained with ethidium bromide. Northern blots of T. claveryi, T. arenaria and yeast rRNA probed with probes mapping to the $5^{\prime}$ and $3^{\prime}$ ends of LSU. Marker is $1 \mathrm{~kb}$ plus (Invitrogen).

\section{Hidden Gap Cleavage Points Are Conserved in Terfezia Species}

To determine the site and sequence of the T. claveryi $28 \mathrm{~S}$ rRNA breakage point, primers to perform $5^{\prime}$ RACE and $3^{\prime}$ RACE were designed. Two cleavage sites, and between them a gap of five nucleotides, were identified after aligning with the T. claveryi LSU rDNA sequence (Figure 3). Different rDNA sequences of Terfezia spp. and T. nivea, which are known to present noncanonical rRNA profiles, were aligned with other Pezizomycetes fungi. All the tested Terfezia and Tirmania rDNA sequences are 


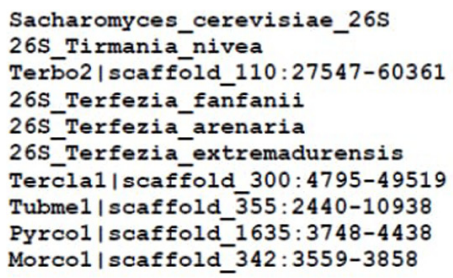

GGTTCCACGTCAACAGCAG-TTGGACGTGGGTTAGTCGATCCTAAGAGATGGGGAAGCTC GGGTTCCATGTGAACAGCAGTTGGCCATGGGTTAGTCGATCCTAAGAGATAGGGAAACTC GGTTCCATGTGAACAGCAGTT-GGCCATGGGTTAGTCGATCCTAAGAGATAGGGAAACTC GGTTCCATGTGAACAGCAGTTTGGCCATGGGTTAGTCGATCCTAAGAGATAGGGAAACTC GGTTCCATGTGAACAGCAGTT-GGCCATGGGTTAGTCGATCCTAAGAGATAGGGAAACTC GGTTCCATGTGAACAGCAGTT-GGCCATGGGTTAGTCGATCCTAAGAGATAGGGAAACTC GGTTCCATGTGAACAGCAGTT-GGCCATGGGTTAGTCGATCCTAAGAGATAGGGAAACTC GGTTCCATGTGAACAGCAG-TTGGACATGGGTTAGTCGATCCTAAGACATAGGGAAATTC GGTTCCATGTGAACAGCAG-TTGGACATGGGTTAGTCGATCCTAAGACATAGGGAAATTC GGCTCCATGTGAACAGCAG-TTGGACATGGGTAAGTCGATCCTAAGACATAGGGAACTC

CGTTTCAAAGGCCTGATTTTATGCAGGCCACCATCGAAAGGGAATCCGG-TTAAGATTCC CGTTTTAAAATGCCTGATTCATCAGGCAATCCCTCGAAAGGGCAGCCGGTTAATATTC-C CGTTTTAAAATGCCTGATTCATCAGGTAATCCCTCGAAAGGGCAGCCGGTTAATATTCTCGTTTTAAAATGCCTGATTCATCAGGTAATCCCTCGAAAGGGCAGCCGGTTAATATTCCC CGTTTTAAAATGCCTGATTCATCAGGTAATCCCTCGAAAGGGCAGCCGGTTAATATTC-C CGTTTTAAAATGCCTGATTCATCAGGTAATCCCTCGAAAGGGCAGCCGGTTAATATTC-C CGTTTTAAAATGCCTGATTCATCAGGTAATCCCTCGAAAGGGCAGCCGGTTAATATTC-C CGTTTCAAAGTGTGCAGTTTGCAT---CACCTGTCGAAAGGGAAG-CCGGTTAAAATTCC CGTTTCAAAGTGTGCAGTTTGCAT---CACCTGTCGAAAGGGAAG-CCGGTTAAAATTCC CGTTTTAAAGTGCGCATTACGCGC---CGCCCGTCGAAAGGGAAG-CCGGTTAAAATTCC

$\begin{array}{ll}\text { GGAACCTGGATATGGATTCTTCACGGTAACGTAACTGAATGTGGAGACGTCGGCGCGAGC } & 1669 \\ \text { GGCACCTGGATGTGGATCTTCGCGGAACGAACTGAACCTGGAGACGTCGGCAGAGGG } & 1668 \\ \text { GGTACCTGGATATAGATTTCATAGTAACATAACTGAACCTGGAGACATCGACAGAGGG } & 1667 \\ \text { GGCACCTGGATGTGGATTTTCGCGGCAACGAACTGAACCTGGAGACGTCGGCAGAGGG } & 1669 \\ \text { GGCACCTGGATGTGGATTTTCGCGGTACGCAACTGAACCTGGAGACGTCGGCAGAGGG } & 1668 \\ \text { GGCACCTGGATGTGGATTTTCGCGGCAACGCAACTGAACCTGGAGACGTCGGCAGAGGG } & 1667 \\ \text { GGCACCTGGATGTGGATTTTCGCGGTAACGCAACTGAACCTGGAGACGTCGGCAGAGGG } & 1667 \\ \text { GGCACCTGGATGTGGACTCTCCACGGTAACGTAACTGAACTCGGAGACGTCGGCGGGGC } & 1664 \\ \text { GGCACCTGGATGTGGACTCTCCACGGTAACGTAACTGAACTCGGAGACGTCGGCGGGGGC } & 1664 \\ \text { GGCACCTGGATGTGGATCTCCACGGCAACGTAACTGAACTCGGAGACGTCGGCGGGGC } & 1664\end{array}$

FIGURE 3 | Alignment of the nucleotides encompassing the hidden gap of 26S rDNA sequences of T. boudieri (Terbo2; JGl), T. claveryi (Tercla1; JGI), Tuber melanosporum (Tubme1; JGI), Pyronema confluens (Pyrco1; JGI), Morchella conica (Morco; JGI), T. arenaria (MH160402), T. extremadurensis (MH160403), T. fanfani (MH160404), T. nivea (MH160405), and Saccharomyces cerevisae (NR_132209.1). Sequences were aligned using the Clustal Omega program. Asterisks indicate the nucleotides that are identical in all sequences analyzed. Red nucleotides indicate the hidden gap. Nucleotides shaded yellow indicate a region conserved in all hidden gap species but divergent in other species. Nucleotides shaded green indicate the possible UAAU tracts downstream of the $26 S \beta$ segment (Macharia et al., 2015).

conserved in the five nucleotide gap, nine nucleotides upstream the gap and 10 nucleotides downstream the gap. In fact, these 24 nucleotides (shaded in yellow in Figure 3) seem to be a hypervariable region D7 within the LSU. This region D7 has been identified for being the closest downstream variable region to the conserved primer LR7 in the alignment. Four nucleotides downstream of the $26 S \beta \_5^{\prime}$ extreme can be identified as a UAAU tract (Figure 3).

\section{DISCUSSION}

The LSU gene is organized into several highly conserved nuclei interrupted by 12 divergent domains, also called "expansion segments" (Clark et al., 1984) or "D domains" (Hassouna et al., 1984). Unlike nuclei, D domains show a high rate of insertions and deletions (Hassouna et al., 1984; Olsen and Woese, 1993). The fundamental importance of rRNA for the synthesis of proteins imposes evolutionary constriction on this type of structures. The insertion of sequences that alter the structure of the rRNA in the divergent domains would be negatively adaptive, unless they were accompanied by the removal of this inserts in the mature rRNA, similar to the excision of the ITS and ETS (internal and external transcribed spacer) (Melen et al., 1999). If the excision occurs in a region that does not need to be covalently continuous to be functional, the result can be a functional "fragmented" rRNA (Melen et al., 1999; Azpurua et al., 2013). In a wide range of biological groups, a double-cut event producing excised fragments of variable length, referred to as "hidden gap" (Ishikawa, 1977a), has been reported, resulting in a non-canonical profile of rRNA bands where $28 \mathrm{~S}$ rRNA band is nearly or totally absent.

In this study, the lack of $28 \mathrm{~S}$ rRNA after heat treatment in some desert truffles, is not due to unspecific degradation since the resulting fragments can be detected by Northern blot. Rather, it should be interpreted as a cleavage molecule with hydrogen bonds joining the $3^{\prime}$ and $5^{\prime}$ portions (28S $\alpha$ and $\beta$, respectively). In this respect, the Northern blot of $T$. claveryi allowed also us to identify a very faint band, suggesting that very low amounts of the immature species were still present (Applebaum et al., 1966; Ishikawa and Newburgh, 1972) or that the hidden gap species of LSU is specific of some cell types (Melen et al., 1999; Azpurua et al., 2013), which consitute the ascocarp although the same post-transcriptional cleavage was also observed in mycelium.

This post-transcriptional maturation of T. claveryi LSU rRNA results in two molecules of 1.6 and $1.8 \mathrm{~kb}$, corresponding to the $5^{\prime}$ and $3^{\prime}$ ends, which has not been previously observed in fungi even when it seems to be widespread in others kingdom, including bacteria, protozoa, worms, several arthropods, fish and rodents (Stevens and Pachler, 1972; 
Lava-Sanchez and Puppo, 1975; Pellegrini et al., 1977; Eckert et al., 1978; Leon et al., 1978; Leipoldt and Engel, 1983; Ware et al., 1985; Burgin et al., 1990; Mertz et al., 1991; van Keulen et al., 1991; Azpurua et al., 2013).

This breakage was located by RACE between 1,566 and 1,570 nucleotides from LSU $5^{\prime}$ extreme. The hidden gap region and the nucleotides surrounding it are located within the D7 domain (Hassouna et al., 1984). Although the size of the gap region differs among organisms, the gap sequence resided in the same region within the $28 \mathrm{~S}$ rRNA, locating in the D7a expansion segment of eukaryotes (Hassouna et al., 1984; Rijk et al., 1994).

To date, the species where the hidden gap has been observed belong to Terfezia genus [T. claveryi, T. arenaria (Figure 1), T. extremaduriensis, T. fanfani, T. boudieri (data not shown)] and even to the closest genus Tirmania (Figure 1), but have not been reported in other Pezizomycetes such as Picoa lefbvrei (Figure 1), Tuber melanosporum, Morchella conica, or Pyronema confluens. During Pezizomycetes evolution, the introduction of sequences susceptible to cleaving to form a hidden gap must have appeared relatively late in their evolution, since, as far as we know, few genera share the hidden gap within the Pezizomycetes order.

The molecular mechanism behind the introduction of this hidden break remains unclear. Microinjecting Sciara coprophila rDNA into Xenopus laevis oocytes confirmed that during pre$28 \mathrm{~S}$ rRNA fragmentation, specific processing machinery is not required. Instead, oocytes may provide the required accessory factors, suggesting that the gap processing mechanism is served by an evolutionarily conserved apparatus (Basile-Borgia et al., 2005). Alternatively, these results may suggest that processing in some lineages is an autocatalytic property of the rRNA (Basile-Borgia et al., 2005). Nishimura et al. (2010) showed that RH39 is a DEAD box protein involved in post-maturation processing of the hidden gap in chloroplast $23 \mathrm{~S}$ rRNA and, recently, RH50 has been identified as another plastid 23S rRNA maturation factor for correct 23S rRNA cleavage (Paieri et al., 2017). The cleavage site has been correlated with a UAAU tract downstream of the $\beta$ segment (Fujiwara and Ishikawa, 1986; Ogino et al., 1990; Sun et al., 2012; Macharia et al., 2015). As well as other organisms, T. claveryi and T. boudieri present the UAAU tract downstream of the $26 \mathrm{~S} \beta$ rRNA.

Regarding the possible biological role of this posttranscriptional maturation, several interpretations have been proposed. One theory proposes a compensatory protein translation rate of hidden gap ribosomes since they show reduced efficiency for protein synthesis in vitro within tetraploid Cyprinid species (Leipoldt and Engel, 1983). The second interpretation is based in the substantially higher translation fidelity of naked mole rat cells with respect to mouse cells. Naked mole rat is well-adapted to extreme environments and has an unusually long life span, which has been correlated

\section{REFERENCES}

Applebaum, S. W., Ebstein, R. P., and Wyatt, G. R. (1966). Dissociation of ribosomal ribonucleic acid from silkmoth pupae by heat and dimethylsulfoxide: with higher translation fidelity of its ribosomes (Azpurua et al., 2013). Additionally, the chloroplast ribosomes of an Arabidopsis thaliana mutant, which exhibit defective chloroplast 23S rRNA fragmentation, have a drastically reduced level of ribulose-1,5-bisphosphate carboxylase/oxygenase and of other chloroplast-encoded photosynthetic proteins (Nishimura et al., 2010). The third interpretation proposes a ribosomal inactivating control mechanism in response to stress conditions by involving the splitting of $60 \mathrm{~S}$ subunits containing $28 \mathrm{~S}$ rRNA with a central hidden break (Nomura et al., 2016). Terfezia species, which are also adapted to extreme environments, display high resistance to drought and high temperatures (Navarro-Ródenas et al., 2011, 2012, 2013; Honrubia et al., 2014; Zambonelli et al., 2014). Whether Terfezia 28S rRNA influences translation efficiency and what impact this can have on its biological cycle is still unknown and deserves further research.

\section{AUTHOR CONTRIBUTIONS}

AN-R, AC, and AM conceived and designed research. AN-R and AC completed the experiments and analyzed the data. AN-R wrote the manuscript. AC and AM reviewed the manuscript. AM provided financial support.

\section{FUNDING}

This work was supported by projects CGL2016-78946-R (AEI/FEDER, UE) and 19484/PI/14 (FEDER/Fundación SénecaAgencia de Ciencia y Tecnología de la Región de Murcia, Spain).

\section{ACKNOWLEDGMENTS}

AN-R is grateful to the University of Murcia for a post-doctoral contract. The authors thank Dr. Giorgio Gambino and Dr. Massimo Turina (IPSP-CNR, Turin) for allowing us to carry out experiments in his laboratory and for providing yeast strains, respectively. They are grateful to Dr. F. Martin, the Mycorrhizal Genomics Initiative consortium for access to genome data. The genome sequence data were produced by the United States Department of Energy Joint Genome Institute in collaboration with the user community.

\section{SUPPLEMENTARY MATERIAL}

The Supplementary Material for this article can be found online at: https://www.frontiersin.org/articles/10.3389/fmicb. 2018.00994/full\#supplementary-material

Evidence for specific cleavage points. J. Mol. Biol. 21, 29-41. doi: 10.1016/00222836(66)90077-5

Azpurua, J., Ke, Z., Chen, I. X., Zhang, Q., Ermolenko, D. N., Zhang, Z. D., et al. (2013). Naked mole-rat has increased translational fidelity compared with the 
mouse, as well as a unique $28 \mathrm{~S}$ ribosomal RNA cleavage. Proc. Natl. Acad. Sci. U.S.A. 110, 17350-17355. doi: 10.1073/pnas.1313473110

Basile-Borgia, A., Dunbar, D., and Ware, V. (2005). Heterologous rRNA gene expression: internal fragmentation of Sciara coprophila $28 \mathrm{~S}$ rRNA within microinjected Xenopus laevis oocytes. Insect Mol. Biol. 14, 523-536. doi: 10.1111/j.1365-2583.2005.00583.x

Burgin, A. B., Parodos, K., Lane, D. J., and Pace, N. R. (1990). The excision of intervening sequences from Salmonella 23S ribosomal RNA. Cell 60, 405-414. doi: 10.1016/0092-8674(90)90592-3

Chang, S., Puryear, J., and Cairney, J. (1993). A simple and efficient method for isolating RNA from pine trees. Plant Mol. Biol. Rep. 11, 113-116. doi: 10.1007/ BF02670468

Clark, C. G., Tague, B. W., Ware, V. C., and Gerbi, S. A. (1984). Xenopus laevis $28 \mathrm{~S}$ ribosomal RNA: a secondary structure model and its evolutionary and functional implications. Nucleic Acids Res. 12, 6197-6220. doi: 10.1093/nar/12. 15.6197

Eckert, W. A., Kaffenberger, W., Krohne, G., and Franke, W. W. (1978). Introduction of hidden breaks during rRNA maturation and ageing in Tetrahymena pyriformis. FEBS J. 87, 607-616. doi: 10.1111/j.1432-1033.1978. tb12413.x

Fujiwara, H., and Ishikawa, H. (1986). Molecular mechanism of introduction of the hidden break into the $28 \mathrm{~S}$ rRNA of insects: implication based on structural studies. Nucleic Acids Res. 14, 6393-6401. doi: 10.1093/nar/14. 16.6393

Hassouna, N., Mithot, B., and Bachellerie, J.-P. (1984). The complete nucleotide sequence of mouse $28 \mathrm{~S}$ rRNA gene. Implications for the process of size increase of the large subunit rRNA in higher eukaryotes. Nucleic Acids Res. 12, 3563-3583. doi: 10.1093/nar/12.8.3563

Honrubia, M., Andrino, A., and Morte, A. (2014). "Domestication: preparation and maintenance of plots," in Desert Truffles - Phylogeny, Physiology, Distribution and Domestication, eds V. Kagan-Zur, N. Roth-Bejerano, Y. Sitrit, and A. Morte (Berlin: Springer-Verlag), 367-387. doi: 10.1007/978-3-642-40096$4 \_21$

Honrubia, M., Cano, A., and Molina-Ninirola, C. (1992). Hypogeous fungi from southern Spanish semiarid lands. Persoonia 14, 647-653.

Ishikawa, H. (1977a). Comparative studies on the thermal stability of animal ribosomal RNA's-IV. Thermal stability and molecular integrity of ribosomal RNA's from several protostomes (rotifers, round-worms, liver-flukes and brineshrimps). Comp. Biochem. Physiol. Part B 56, 229-234. doi: 10.1016/03050491(77)90005-0

Ishikawa, H. (1977b). Evolution of ribosomal RNA. Comp. Biochem. Physiol. Part B 58, 1-7. doi: 10.1016/0305-0491(77)90116-X

Ishikawa, H., and Newburgh, R. (1972). Studies of the thermal conversion of $28 \mathrm{~S}$ RNA of Galleria mellonella (L.) to an 18 S product. J. Mol. Biol. 64, 135-144. doi: 10.1016/0022-2836(72)90325-7

Kay, R., Chan, A., Daly, M., and McPherson, J. (1987). Duplication of CaMV 35S promoter sequences creates a strong enhancer for plant genes. Science 236, 1299-1302.

Lava-Sanchez, P., and Puppo, S. (1975). Occurrence in vivo of "hidden breaks" at specific sites of $26 \mathrm{~S}$ ribosomal RNA of Musca carnaria. J. Mol. Biol. 95, 9-20. doi: 10.1016/0022-2836(75)90331-9

Leaver, C. (1973). Molecular integrity of chloroplast ribosomal ribonucleic acid. Biochem. J. 135, 237-240.

Leipoldt, M., and Engel, W. (1983). Hidden breaks in ribosomal RNA of phylogenetically tetraploid fish and their possible role in the diploidization process. Biochem. Genet. 21, 819-841. doi: 10.1007/BF00498929

Leon, W., Fouts, D. L., and Manning, J. (1978). Sequence arrangement of the $16 \mathrm{~S}$ and 26S rRNA genes in the pathogenic haemoflagellate Leishmania donovani. Nucleic Acids Res. 5, 491-504. doi: 10.1093/nar/5.2.491

Macharia, R. W., Ombura, F. L., and Aroko, E. O. (2015). Insects' RNA profiling reveals absence of "hidden break" in $28 \mathrm{~S}$ ribosomal RNA molecule of onion thrips, Thrips tabaci. J. Nucleic Acids 2015:8. doi: 10.1155/2015/ 965294

Melen, G. J., Pesce, C. G., Rossi, M. S., and Kornblihtt, A. R. (1999). Novel processing in a mammalian nuclear $28 \mathrm{~S}$ pre-rRNA: tissue-specific elimination of an 'intron' bearing a hidden break site. EMBO J. 18, 3107-3118. doi: 10.1093/ emboj/18.11.3107
Mertz, P. M., Bobek, L. A., Rekosh, D. M., and LoVerde, P. T. (1991). Schistosoma haematobium and S. japonicum: Analysis of the ribosomal RNA genes and determination of the "gap" boundaries and sequences. Exp. Parasitol. 73, 137-149. doi: 10.1016/0014-4894(91)90017-Q

Moreno, G., Alvarado, P., and Manjón, J. L. (2014). "Hypogeous desert fungi," in Desert Truffles - Phylogeny, Physiology, Distribution and Domestication, eds V. Kagan-Zur, N. Roth-Bejerano, Y. Sitrit, and A. Morte (Berlin: Springer-Verlag), 3-20. doi: 10.1007/978-3-642-40096-4_1

Morte, A., and Andrino, A. (2014). "Domestication: preparation of mycorrhizal seedlings," in Desert Truffles - Phylogeny, Physiology, Distribution and Domestication, eds V. Kagan-Zur, N. Roth-Bejerano, Y. Sitrit, and A. Morte (Berlin: Springer-Verlag), 343-365. doi: 10.1007/978-3-642-40096-4_21

Morte, A., Honrubia, M., and Gutiérrez, A. (2008). "Biotechnology and cultivation of desert truffles," in Mycorrhiza, ed. A. Varma (Berlin: Springer), 467-483. doi: 10.1007/978-3-540-78826-3_23

Morte, A., Navarro-Ródenas, A., and Nicolás, E. (2010). Physiological parameters of desert truffle mycorrhizal Helianthemum almeriense plants cultivated in orchards under water deficit conditions. Symbiosis 52, 133-139. doi: 10.1007/ s13199-010-0080-4

Morte, A., Pérez-Gilabert, M., Gutiérrez, A., Arenas, F., Marqués-Gálvez, J. E., Bordallo, J. J., et al. (2017). "Basic and applied research for desert truffle cultivation," in Mycorrhiza - Eco-Physiology, Secondary Metabolites, Nanomaterials, eds A. Varma, R. Prasad, and N. Tuteja (Cham: Springer International Publishing), 23-42. doi: 10.1007/978-3-319-57849-1_2

Navarro-Ródenas, A., Bárzana, G., Nicolás, E., Carra, A., Schubert, A., and Morte, A. (2013). Expression analysis of aquaporins from desert truffle mycorrhizal symbiosis reveals a fine-tuned regulation under drought. Mol. Plant Microbe Interact. 26, 1068-1078. doi: 10.1094/MPMI-07-120178-R

Navarro-Ródenas, A., Lozano-Carrillo, M. C., Pérez-Gilabert, M., and Morte, A. (2011). Effect of water stress on in vitro mycelium cultures of two mycorrhizal desert truffles. Mycorrhiza 21, 247-253. doi: 10.1007/s00572-0100329-z

Navarro-Ródenas, A., Ruíz-Lozano, J. M., Kaldenhoff, R., and Morte, A. (2012). The aquaporin TcAQP1 of the desert Truffle Terfezia claveryi is a membrane pore for water and CO2 transport. Mol. Plant Microbe Interact. 25, 259-266. doi: 10.1094/MPMI-07-11-0190

Nishimura, K., Ashida, H., Ogawa, T., and Yokota, A. (2010). A DEAD box protein is required for formation of a hidden break in Arabidopsis chloroplast 23S rRNA. Plant J. 63, 766-777. doi: 10.1111/j.1365-313X.2010.04276.x

Nomura, T., Ito, M., Kanamori, M., Shigeno, Y., Uchiumi, T., Arai, R., et al. (2016). Characterization of silk gland ribosomes from a bivoltine caddisfly, Stenopsyche marmorata: translational suppression of a silk protein in cold conditions. Biochem. Biophys. Res. Commun. 469, 210-215. doi: 10.1016/j.bbrc.2015.11.112

Ogino, K., Eda-Fujiwara, H., Fujiwara, H., and Ishikawa, H. (1990). What causes the aphid 28S rRNA to lack the hidden break? J. Mol. Evol. 30, 509-513.

Olsen, G. J., and Woese, C. R. (1993). Ribosomal RNA: a key to phylogeny. FASEB J. 7, 113-123. doi: 10.1096/fasebj.7.1.8422957

Paieri, F., Tadini, L., Manavski, N., Kleine, T., Ferrari, R., Morandini, P. A., et al. (2017). The DEAD-box RNA helicase RH50 is a 23S-4.5S rRNA maturation factor that functionally overlaps with the plastid signaling factor GUN1. Plant Physiol. 176, 634-648. doi: 10.1104/pp.17.01545

Pellegrini, M., Manning, J., and Davidson, N. (1977). Sequence arrangement of the rDNA of Drosophila melanogaster. Cell 10, 213-224. doi: 10.1016/00928674(77)90215-X

Rijk, P. D., de Peer, Y. V., Chapelle, S., and Wachter, R. D. (1994). Database on the structure of large ribosomal subunit RNA. Nucleic Acids Res. 22, 3495-3501. doi: 10.1093/nar/22.17.3495

Scotto-Lavino, E., Du, G., and Frohman, M. A. (2006). 5' end cDNA amplification using classic RACE. Nat. Protoc. 1, 2555-2562. doi: 10.1038/nprot.2006.480

Sievers, F., Wilm, A., Dineen, D., Gibson, T. J., Karplus, K., Li, W., et al. (2011). Fast, scalable generation of high-quality protein multiple sequence alignments using Clustal Omega. Mol. Syst. Biol. 7:539. doi: 10.1038/msb.2011.75

Stevens, A., and Pachler, P. (1972). Discontinuity of $26 \mathrm{~s}$ rRNA in Acanthamoeba castellani. J. Mol. Biol. 66, 225-237. doi: 10.1016/0022-2836(72)90475-5

Sun, S., Xie, H., Sun, Y., Song, J., and Li, Z. (2012). Molecular characterization of gap region in $28 \mathrm{~S}$ rRNA molecules in brine shrimp Artemia parthenogenetica 
and planarian Dugesia japonica. Biochemistry 77, 411-417. doi: 10.1134/ S000629791204013X

van Keulen, H., Mertz, P. M., LoVerde, P. T., Shi, H., and Rekosh, D. M. (1991). Characterization of a 54-nucleotide gap region in the $28 \mathrm{~S}$ rRNA gene of Schistosoma mansoni. Mol. Biochem. Parasitol. 45, 205-214. doi: 10.1016/01666851(91)90087-M

Ware, V. C., Renkawitz, R., and Gerbi, S. A. (1985). rRNA proceesing: removal of only nineteen bas at the gap between $28 \mathrm{~S} \alpha$ and $28 \mathrm{~S} \beta$ rRNAs in Sciara coprophila. Nucleic Acids Res. 13, 3581-3597. doi: 10.1093/nar/13.10.3581

Winnebeck, E. C., Millar, C. D., and Warman, G. R. (2010). Why does insect RNA look degraded? J. Insect Sci.10:159. doi: 10.1673/031.010.14119

Zambonelli, A., Donnini, D., Rana, G. L., Fascetti, S., Benucci, G. M. N., Iotti, M., et al. (2014). Hypogeous fungi in Mediterranean maquis, arid and semi-arid forests. Plant Biosyst. 148, 392-401. doi: 10.1080/11263504.2013.877537
Conflict of Interest Statement: The authors declare that the research was conducted in the absence of any commercial or financial relationships that could be construed as a potential conflict of interest.

The handling Editor declared a shared affiliation, though no other collaboration, with one of the authors AC.

Copyright (c) 2018 Navarro-Ródenas, Carra and Morte. This is an open-access article distributed under the terms of the Creative Commons Attribution License (CC BY). The use, distribution or reproduction in other forums is permitted, provided the original author(s) and the copyright owner are credited and that the original publication in this journal is cited, in accordance with accepted academic practice. No use, distribution or reproduction is permitted which does not comply with these terms. 